are apparent, as in Fig. 6. but they differ slightly in their position when compared with Catherwood (Fig. 3).

Stephens mentions that, at times, those engaged in commercial ventures have reached Santo Domingo del Palenque, and proceeded thence to the ancient Maya ruins, called, for want of a better name, Palenque, after the village near which they stand.

We have represented in Fig. 5 a sketch made by Mr. William Robert Thompson, who visited the ruins of Palenque in December, 1852, and again at a later date. Engaged in commercial pursuits in northern Chiapas and other parts of Mexico and Guatemala, Mr. Thompson has examined many of the old Maya cities, especially Qurigia and Palenque, sketching, in leisure moments, such details as he found interesting, preserving them for his own gratification. In looking over his portfolio some years ago I was struck with the resemblance of his drawing (Fig. 5) to that of Waldeck (Fig. 2). Mr. Thompson having returned to Mexico, I wrote to him in 1882 requesting a copy of his sketch, and, with all due courtesy, he presented me with the original, accompanying it with an autograph letter. The letter and sketch I shall forward to the American Philosophical Society of Philadelphia, so that they can be preserved for future examination.

Comparing the Thompson sketch with that of Mr. Waldeck, it will be seen that the latter has omitted the small incised circles which are present in the former, on the har of the cross and at its top and sides, which Mr. Thompson's letter especially mentions as present. Waldeck, in the cross-like glyph, to the right, gives
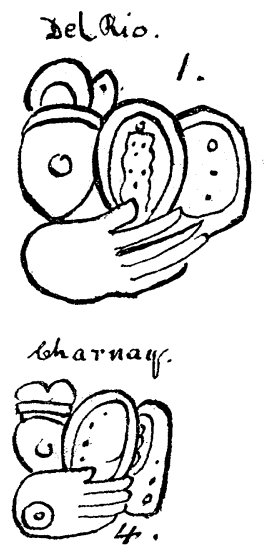
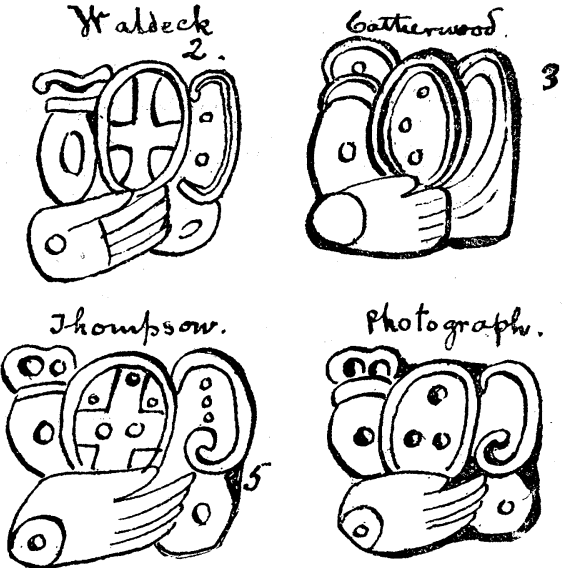
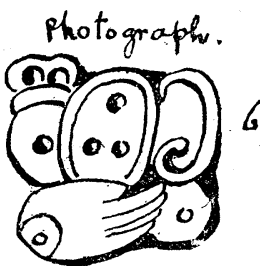

two small circles as its components, and Thompson gires three, which Charnay also indicates in Fig. 5, while both he and Catherwood omit the small round glyph with the incised circle, which is shown at the lower right-hand side in the Urbino photograph (Fig. 6), also in the sketches of Waldeck and Thompson. It is not surprising that so careful a draftsman as Catherwood should have omitted details in drawing this glyph, ill as he was with fever and subjected to annoyances which only those who bave encountered them can appreciate.

All of the drawings of this (Fig. 6) glyph differ more or less; those of Waldeck and Thompson hare four of the small glyphs represented with a fair degree of exactitude, accepting the photograph as our standard; Catherwood and Charnay have three details of the compound glyph which are, in a measure, correct. The fact that Messrs. Waldeck and Thompson both give a symbol resembling the symbol of the cardinal points as a component of the glyph which we are considering, suggests a probability that it existed and has been effaced. The surface of the glyph at present being so mutilated it would be best to examine the original tablet with care before deciding the matter, which I hope someone interested in palæography will have the opportunity of doing in the near future. The position of the three small circles in Fig. 6 correspond with the Thompson sketch (Fig. 5), even if the cross is absent, and, as Thompson gives an incised circle to either side of the cross at the top, it is not improbable that a series of dotted lines, or circles, at one time ran completely around the glyph, as we see a slight suggestion of this in Charnay's sketch (Fig. 4), and also in Catherwood's Fig. 3. Mr. Thompson asserts, positively, in his letter, that a cross did exist, and that the three incised circles were present on its perpendicular and parallel bars. He has, in a recent conversation upon the suhject, expressed the belief that this symbol of the winds has been mutilated intentionally, and that the two circles at the sides of the pe:pendicular bar are quite recent additions, made by someone trying to alter the glyph into the semblance of a face. Two small circles on either side suggest the eses, and the upper portion of the perpendicular upright above heing mutilated across, just beyond its point of junction with the parallel bar, thus produces a semblance to a nose, the parallel bar assuming somewhat the appearance of a mouth. This seems to be the case in the small Urbino photograph, but in the enlarged copy the mutilation of the glyph is more apparent, yet, as we have suggested, these matters can only be decided upon by a careful study of the original tablet.

A realistic drawing of the upper-centre component of this hieroglyph would be of great value for comparison with the photograph, as there are some details which the camera does not reproduce. If some of our artists visiting the Muséo Nacional, at the City of Mexico, would make a careful drawing of the Casa No. 2 tablet, it would be of great value to those engaged in the study of Maya palæography, and no doubt determine the question whether a cross and its dots (Fig. 5) are to be accepted as the true components of the glyph, or the details given in Fig. 6 of the plate accompanying this article. Until these doubts be settled, attempts at its interpretation are useless.

\section{THE OSAGE RIVER AND ITS MEANDERS.}

By arthur winslow, office of the geological surVey, JeFFerSON CITY, Mo.

In the remarks upon the Osage River in Miscouri, which form part of his admirable notice of the topographic maps of the U. S. Geological Survey, published in Science of April 28, 1893, Professor Davis has, with great acumen, hit upon one of the most noticeable features of the drainage of the State, or, at least, of the southern part. The peculiar meandering of the deeply trenched Osage Valley around spurs of high upland country, as referred to by us in a recent report of the Geological Survey, ${ }^{1}$ is a feature shared by nearly all of the principal streams of the Ozark region. The Meramec and the Gasconade Rivers, the Big Piney and the Bourbeuse Creeks of the northern slope hare the same swinging course; as have also their tributaries and those of the Osage itself. White River, on the southern slope, in Missouri and Arkansas, is characterized by similar convolutions. The courses of Big River and of the St. Francois River in the southeast have a like aspect. In strong contrast to this are the streams of that portion of the State lying north of the Missouri River-the drift-corered area. Here the courses are, in a general way, straight, of ten parallel in groups, the meanders of the streams confined to their present flood plains; their channels apparently having originated in the mantle of glacial drift. They are comparatively of recent origin, the older drainage system which lies masked beneath the drift may have been more tortuous.

The suggestive explanation which Professor Daris offers for the sunken curved course of the Osage, $i$ e., that it has been developed, through elevation and corrosion, from the flood-plain meanders of the stream, originating during an earlier base-leveled condition of the country, seems a natural explanation and is in many respects satisfactory. Still we hesitate to accept it in the present stage of our knowledge on mere a priori grounds. We see that it calls for a previous base-leveling of the whole Missouri-Ozark region, if not of the contiguous or even remoter Arkansas territory. Further, the hypothesis has so intimate a bearing upon the problems of recent geologic history of this country, ove $r$ and above its relation to the derelopment of the topography, that we wish to see full test made of its sufficiency before we adopt it as an axiom.

According to the best light we have at present, we recognize that the Ozark area was uplifted in late Cambrian times and remained above water level, in part at least, probably until the carboniferous period; that, if entirely submerged during the Mississippian epoch, it was so only long enough to receive but a

$$
1 \text { "Report on Iron Ores," vol. ii, p. } 89 .
$$


thin covering of the rocks of that formation; that these rocks were subjected to subareal erosion before and probably during the Pennsylvanian epoch and that coal-measure strata probably never covered the dome of the uplift; that since this time the region has been continuously above water level. According to this record the sculpturing of the topography must have been uninterruptedly in progress from the end of the Paleozoic to the present time.

Professor Davis sees evidence in the character of the relief that denudation progressed to such a degree that the present upland was a lowland-"well into Tertiary time, and that the new trenckes of the Osage and its neighbors were begun in consequence of an uplift somewhere about the close of Tertiary time" - as opposed to this conclusion we have the fact that the Ozark plateau is at present much above the limits which we recognize Tertiary seas to have reached. The altitude of the Tertiary margin of the Mississippi embayment in southeastern Missouri is ander 400 feet A. T. The summit of the Ozarks is, howerer, as much as 1,700 feet abore sea level and the greater portion of the upland is orer 1,000 feet, and was consequently at least 600 feet above the Tertiary sea level. Could a country having this altitude above contiguous seas be in a base-leveled condition? Further, another fact to reconcile with this hypothesis is the finding of certain chert gravels fringing the Osage and other valleys of the Ozarks, not very high above the present channels of the streams, which we provisionally correlate with the Orange sands pect certain peculiar features of topography to prevail. Thus, with a stream not yet at base level we should look for its channel to constantly hug the hill on that side of the stream which is impinged by the current; here we should expect to find bluffs developed and maintained; conversely, on the "lee" side of the stream, we should expect to find such flat alluvial plains as exist, with comparatively gentle slopes thence to the uplands. Further we should expect to find the points or promontories of uplands which are nearly surrounded by the loops of the river, sloping somewhat gradually towards their ends and not terminating in bluffs. These features are pronounced, in part at least, to a striking degree along the Osage. They are details which could not be brought out on the maps of the scale of those thus far made of the Osage country, but the constancy with which the stream clung to the bluffs on the impinging side was impressively seen during the recent trip along that river, while the form of the projecting uplands is well illustrated by the following copy of a portion of a map of Grand River, one of the tributaries of the Osage, recently surveyed by Mr. C. F. Marbut, of the Missouri Geological Survey. On the hypothesis advanced the precipitous slopes characterizing the upstream sides of the hills here shown are the result of the sapping action of the stream; the gradual slopes of the downstream sides are primarily a combined result of the lateral movement of the channel accompanying the expansion of the meanders, and of its downward movement by corrosion.

It is true that similar features would result with the trench of

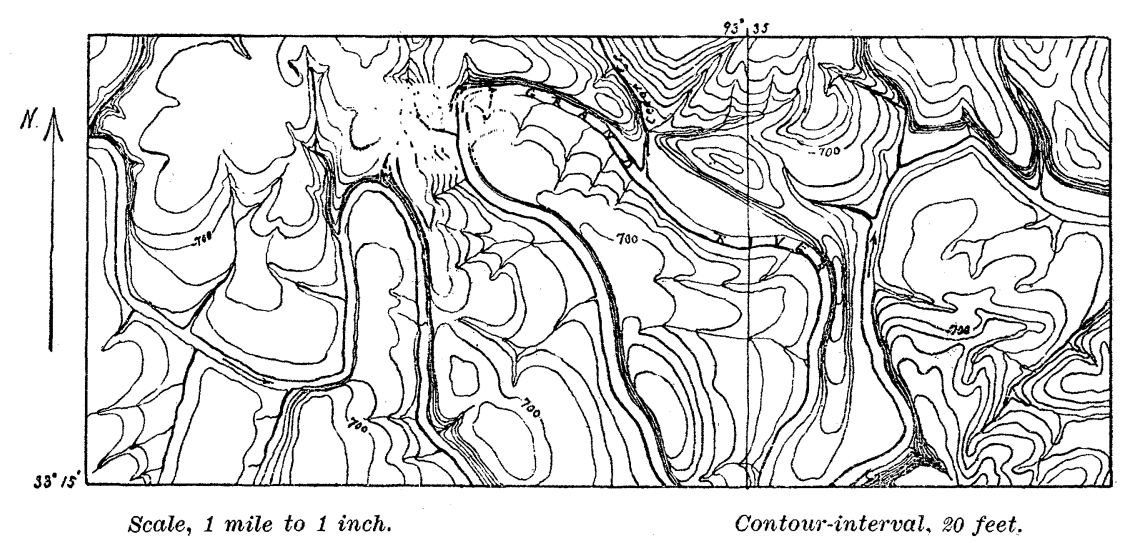

MEANDERS OF GRAND RIVER, A TRIBUTARY OF THE OSAGE.

of the Mississippi, of probable late Tertiary age. These imply the existence of such valleys with approximately their present phases in late Tertiary times. Still, as the correlation of these gravels is as yet confessedly quite hypothetical, this consideration cannot claim much weight.

Another hypothesis which has been thought by us to suggest an explanation of the sinuosities of these streams, has gained some strength through the observations of a recent boat trip down the Osage River, from Osceola to its mouth. If we take the case of a stream with a slightly sinuous course and of considerable declivity, moderately incised in a nearly flat, or even in an undulating country of horizontal strata-such as might exist in a newly emerged land surface soon after its emergence-we can understand that meanders will tend to develop somewhat as they do in the alluvial plain of a stream which has reached base level. Where the current impinges sapping will increase the convexity and the sinuosities will become more pronounced Inasmuch, however, as the declivity of the stream is great, corrosion is still active and the channel thus sinks vertically at the same time that it moves laterally, and in this respect its development will differ from that of a channel in a base-leveled alluvial plain. As a natural result of this process we can see how the stream will eventually shape for itself a tortuous and steep-sided ralley, with very narrow flood plains until the channel has reached base level, when corrosion will cease and lateral degradation will increase; then, swinging from bluff to bluff in a secondary system of sinuosities, the stream will sap its bordering hills and widen its flood plains. If this explanation be a true one we should ex - previously developed meanders in the manner suggested by Professor Davis ; for we cannot conceive of a meandering channel sinking absolutely vertically. Lateral degradation and movement must always accompany corrosion and vertical lowering of the channel; if the meanders existed originally their shapes must have been modified to the present forms. Hence the effects cited would seem to be attributable to one of two causes, or to both combined. The question is whether one is not all sufficient; whether a prerious base-leveled condition is a necessary assumption.

\section{THE BOOM OF THE PRAIRIE CHICKEN,}

\section{BY T. A. BEREMAN, MOUNT PLEASANT, IOWA.}

How many of your readers erer saw a prairie hen, or, as they are commonly called in the west, the "prairie chicken?" Doubtless many hare seen dead ones, killed and shipped for the market, but I dare say that many of your younger readers, especially those living in the cities and towns, hare rarely seen a live one. In 1845, when I came to Iowa, and for several years afterwards, they could be seen here in flocks of thousands together. But now there are only a few remnants of them left; here and there, in isolated fields, some dozen or two survivals have been permitted to remain. They are what is called the pinnated grouse of North A merica, and were formerly inhabitants of New Jersey, Pennsylvania and Kentucky, and all the western prairie country.

But at present I only desire to call attention to the matinee songs of this wild bird of the prairie. Some morning in the 